\begin{tabular}{|l|l|l||}
\hline \multicolumn{2}{|c|}{ PublisherInfo } \\
\hline \hline PublisherName & $:$ & BioMed Central \\
\hline \hline PublisherLocation & $:$ & London \\
\hline \hline PublisherImprintName & $:$ & BioMed Central \\
\hline \hline
\end{tabular}

\title{
Autoreactive T cells respond to nucleobindin
}

\begin{tabular}{|l|l|l||}
\hline \multicolumn{2}{|c|}{ ArticleInfo } \\
\hline \hline ArticleID & $:$ & 108 \\
\hline \hline ArticleDOI & $:$ & $10.1186 /$ ar-2001-66886 \\
\hline \hline ArticleCitationID & $:$ & 66886 \\
\hline \hline ArticleSequenceNumber & $:$ & 65 \\
\hline \hline ArticleCategory & $:$ & Paper Report \\
\hline \hline ArticleFirstPage & $:$ & 1 \\
\hline \hline ArticleLastPage & $:$ & 3 \\
\hline \hline & & RegistrationDate : 2001-2-23 \\
\hline ArticleHistory & $:$ & OnlineDate \\
\hline \hline ArticleCopyright & $:$ & Biomed Central Ltd2001-2-23 \\
\hline \hline ArticleGrants & $:$ & \\
\hline \hline ArticleContext & $:$ & 130753311 \\
\hline \hline
\end{tabular}


Aff1 CNRS, Strasbourg, France

\section{Keywords}

Anti-DNA antibodies, autoreactive T cells, lupus mice, nucleobindin, autoreactive $\mathrm{T}$ cells, lupus mice, nucleobindin, autoreactive $\mathrm{T}$ cells, lupus mice, nucleobindin

\section{Context}

Nucleobindin (Nuc) was originally identified as a $55 \mathrm{kDa}$ protein that enhanced anti-DNA antibody production when added to cultures of autoimmune MRL/lpr mouse spleen cells. Nuc is a DNA- and calcium-binding leucine zipper protein whose physiological functions remain unknown. In previous studies, the authors showed that Nuc is not only able to augment anti-DNA production in vitro, but also to accelerate the autoimmune response in vivo in MRL/+/+ mice. Moreover, Nuc mRNA expression was found to be increased in lymphatic organs of lupus mice. To verify if Nuc is involved in anti-DNA production by stimulating autoreactive $\mathrm{T}$ cells, the authors studied the $\mathrm{T}$-cell response both in lupus mice and in normal mice injected with recombinant Nuc (rNuc).

\section{Significant findings}

Spleen cells from 6-, 11- or 29-week-old MRL/lpr mice proliferated when cultured in the presence of $25 \mathrm{~g} / \mathrm{ml} \mathrm{rNuc}$. A higher proliferative response was observed in 6-week-old mice, and progressively decreased during the course of the disease. T-cell lines from BALB/c mice repeatedly injected with $\mathrm{rNuc}$ proliferate in response to Nuc. Nuc is probably presented in the context of MHC class II, since the response was abolished by the addition of antibody to I-Ad molecule. Finally T cells alone were unable to induce anti-dsDNA secretion in BALB/c mice, but enhanced their production when co-injected with rNuc.

\section{Comments}

This study demonstrates that $\mathrm{T}$ cells from lupus mice can be activated in the presence of Nuc, and that T-cell lines specific for rNuc can provide help for the production of anti-dsDNA antibodies by B cells 
from BALB/c mice injected with rNuc. Previous studies had shown that Nuc is present in culture supernatant of MRL/lpr mice and is increased in their lymphatic organs, suggesting that the overexpression and secretion of the protein may be involved in the activation of autoreactive $\mathrm{T}$ cells. The author did not comment on the production of Nuc in human lupus, nor in other murine lupus models such as NZBxNZW F1. Moreover, no data are presented addressing whether Nuc is itself the target of autoantibodies. The authors have not commented on the fact that nucleobindin was recently shown to be a Golgi resident protein, apparently involved in $\mathrm{Ca}^{2+}$ storage, and it seems that it is not primarily localized in the nucleus as originally described (see Additional information).

\section{Methods}

T-cell lines, proliferation assays, ELISA

\section{Additional information}

Lin P, Yao Y, Hofmeister R, Tsien RY, Farquhar MG: Overexpression of CALNUC (nucleobindin) increases agonist and thapsigargin releasable Ca2+ storage in the Golgi. J Cell Biol 1999, 145:279-289 (PubMedabatract).

Lin P, Le-Niculescu H, Hofmeister R, McCaffery JM, Jin M, Hennemann H, McQuistan T, De Vries L, Farquhar MG: The mammalian calcium-binding protein, nucleobindin (CALNUC), is a Golgi resident protein. J Cell Biol 1998, 141:1515-1527 (PubMedabstract).

\section{References}

1. Kubota T, Watanabe N, Kaneko T, Satake F, Miura K, Kurosawa Y, Miyasaka N, Kanai Y: Activation of autoreactive $\mathrm{T}$ cells that help nucleobindin-injected mice produce anti-DNA antibodies. Immunol Lett. 2001, 75: 111-115.

This PDF file was created after publication. 